\title{
Quantitative Trait Loci for Tomato Yellow Leaf Curl Virus and Tomato Mottle Virus Resistance in Tomato
}

\author{
H.A. Agrama ${ }^{1}$ and J.W. Scott \\ Gulf Coast Research and Education Center, University of Florida, 14625 CR 672, Wimauma, \\ FL 33598
}

AdDitional INDEX wORDS. Lycopersicon chilense, mapping, QTL, RAPD, ToMoV, TYLCV

\begin{abstract}
The genetic basis of resistance to tomato yellow leaf curl virus (TYLCV) and tomato mottle virus (ToMoV) was studied in three different mapping populations of tomato (Lycopersicon esculentum Mill.). Bulked segregant analysis (BSA) was used to identify random amplification of polymorphic DNA (RAPD) markers linked to TYLCV and ToMoV resistance. Segregated RAPD markers associated with resistance were linked to morphological markers self-pruning $(s p)$ and potato leaf $(c)$ on chromosome 6. RAPD genetic linkage maps of chromosome 6 were constructed for each of the three populations. Common mapped markers revealed straightforward homologies between the chromosome 6 linkage group of the three populations. Multiple-QTL mapping (MQM) was used to identify quantitative trait loci (QTL) for resistance linked to chromosome 6. These revealed that the resistance against TYLCV and ToMoV was mainly explained by two QTL in two populations and one QTL in another. For all of the resistance QTL detected, the favorable allele was provided by the resistant parents. The presence of three different sources of TYLCV and ToMoV resistance, and the markers in tight linkage with them, provide a means of systemically combining multiple resistance genes. Successful cloning of the $R$ gene from tomatoes would lead to deeper understanding of the molecular basis of resistance to TYLCV and ToMoV, and might also shed light on the evolution of resistance genes in plants in general.
\end{abstract}

Tomato yellow leaf curl virus (TYLCV) and tomato mottle virus (ToMoV) are transmitted by adult silverleaf whiteflies $[B e$ misia tabaci (Gennadius) Biotype B (B. argentifolii Bellows \& Perring)]. TYLCV was first described in Israel in 1939-40 (Picó et al., 1996), associated with outbreaks of B. tabaci. TYLCV has caused economically significant yield losses in tomato (L.esculentum Mill.) in the eastern Mediterranean region for many years and has spread to many countries in the Mediterranean (Ioannou, 1987), Middle East (Cohen et al., 1988), Africa (Lana and Wilson, 1976), Asia (Verma et al., 1975), and Australia (Dry et al., 1993). In the early 1990s, symptoms characteristic of TYLCV-Is were observed in the Dominican Republic, Cuba, and Jamaica (Polston et al., 1994). TYLCV was identified in 1997 in southern Florida (Polston et al., 1999) and spread to the north rapidly; it was first identified in northern Florida and southern Georgia in Fall 1998 (Momol et al., 1999). In 2000, the disease was reported for the first time in Greece (Avgelis et al., 2001) and in the Canary Islands and Morocco (Monci et al., 2000). TYLCV has a broad host range from several plant families, including Solanaceae, Malvaceae, Fabaceae, and ornamental and weed species. However, tomato is the crop that is most often afflicted.

In 1989, tomato plants with unusual virus-like symptoms were identified in southwestern Florida (Kring et al., 1991) and the pathogen was identified as a unique bipartite geminivirus now known as ToMoV (Abouzid et al., 1992). ToMoV causes leaf curling, epinasty stunting of growth, and reduction in leaf size and yield (Griffiths and Scott, 2001; Polston et al., 1993). Weakening of the whole tomato plant, and flower and fruit abscission caused by TYLCV infection result in serious yield losses, up to $100 \%$ in many tropical and subtropical regions. These losses are particularly severe when the infection occurs before flowering. In

Received for publication 4 May 2005. Accepted for publication 16 Aug. 2005. Present address: Rice Research and Extension Center, University of Arkansas, Stuttgart, AR 72160; e-mail: hagrama@uark.edu many areas, TYLCV has become the main factor limiting tomato production in both outdoor and protected crops. It is also a threat to many regions where the tomato crop is being expanded.

Several sources of resistance to TYLCV have been studied and they showed different modes of inheritance. Resistance from $L$. pimpinellifolium (Jusi.) Mill. was conferred by a partially dominant gene $T y-1$ (Pilowsky and Cohen, 1974), as was resistance from L. chilense that was identified by Zamir et al. (1994). A single dominant gene, Tylc, derived from L. pimpinellifolium (Kasarawi, 1989) and another from L. chilense (Gomez and Laterrot, 1997) conferred resistance. The crosses $L$. esculentum cv. UC82 $\times L$. cheesmanii Riley ssp. minor (Hook f.) C.H. Müller LA1401, and L. esculentum cv. VF145B7879 x L. hirsutum Humb. \& Bonpl. LA386 were studied by Hassan et al. (1984). Reactions of parents, $\mathrm{F}_{2}$ and $\mathrm{F}_{3}$ plants, and backcrosses of resistant $\mathrm{F}_{2}$ plants to UC82 indicated that resistance derived from $L$. cheesmanii appears to be recessive and the narrow-sense heritability was 0.44 . Reaction of parental, $\mathrm{F}_{1}, \mathrm{~F}_{2}$, and backcross plants indicated that resistance derived from L. hirsutum is dominant and controlled by more than one gene. A recessive tolerance (Pilowsky and Cohen, 1990) was based on five genes from L. peruvianum (L.) Mill. A recent study revealed that the number of genes controlling the tolerance character was estimated as three in L. pimpinellifolium accessions and four in L. pennellii (Corr.) D'Arcy LA 716 and the narrow-sense heritability estimate was 33\% (Hassan and Abdel-Ati, 1999). The results obtained from these wild species with segregating populations showed that tolerance is additive and depends upon genetic sources from L. pimpinellifolium, which is controlled by one major gene, that from $L$. chilense by two genes, and that from L. peruvianum by three genes with no dominant effect (Vidavsky et al., 1998). Little genetic work has been reported for bipartite geminiviruses. Wild tomato accessions of $L$. chilense were found to have the best resistance to ToMoV (Scott and Schuster, 1991). Introgression of resistance into L. esculentum resulted in $3.4 \%$ of backcross plants in higher resistance 
categories, which revealed that ToMoV resistance was controlled by more than one gene (Scott et al., 1995). ToMoV resistance was found to be correlated to indeterminate $\left(s p^{+}\right)$plants, indicating possible linkage of resistance to the $s p$ locus on chromosome 6. Later, this was confirmed by Griffiths and Scott (2001), who found that two resistance loci on chromosome 6 with additive effects conferred resistance from $L$. chilense accession LA 1932. ToMoV-resistant inbreds generally have been resistant to TYLCV, as found by Griffiths and Scott (2001).

The identification of molecular markers linked to resistance genes is particularly useful for both marker-assisted selection (MAS) and map-based gene cloning (Tanksley et al., 1995). So far, a number of restriction fragment length polymorphism (RFLPs) and RAPD markers have been found to be linked to TYLCV and ToMoV resistance genes. The partially dominant major gene $T y-1$ has been mapped to the 13-cM interval between RFLP markers TG97 and TG25 on the short arm of chromosome 6 (Zamir et al., 1994). Mapping a wild tomato L. hirsutum introgression associated with TYLCV resistance in a cultivated tomato (L. esculentum) line showed that chromosome 11 spanned RFLP markers TG36 to TG393, a distance of $14.6 \mathrm{cM}$ (Hanson et al., 2000). Bulked segregant analysis (BSA) was used to identify four RAPD markers linked to TYLCV resistance in a 17.3-cM region on chromosome 6 (Chagué et al., 1997). Also, BSA was applied in a recent study (Griffiths and Scott, 2001) to identify RAPD markers linked to ToMoV resistance derived from L. chilense accession LA1932. Twelve markers segregated into two linked regions flanking either side of the morphological markers self-pruning ( $s p)$ and potato leaf (c) on chromosome 6. Griffiths (1998) also found that a third region encompassing the $T y-1$ gene was associated with resistance to ToMoV in accessions LA 2779 and LA 1938. The objective of this present study was to search for evidence of novel QTL affecting TYLCV and ToMoV resistance from different tomato resources by applying MQM. This study was also performed to develop fine-scale genetic maps of chromosome 6 in each of three $\mathrm{F}_{2}$ populations.

\section{Materials and Methods}

Three tomato $\mathrm{F}_{2}$ mapping populations were developed for this study, using three different genetic resistance sources. Resistant inbreds derived from L. chilense genotypes LA1932, LA2779, and LA1938/Tyking were each crossed with susceptible Florida heat-tolerant breeding line Fla 7324. The developed populations were designated as 503, 506, and 509, respectively. Subsequently, $\mathrm{F}_{1}$ seed of each was bulked to obtain the three $\mathrm{F}_{2}$ progenies. Parents and $\mathrm{F}_{2}$ plants were grown in two sets of Todd planter flats (Speedling, Sun City, Fla.). TYLCV and ToMoV were field screened in Fall 2000 and Spring 2001 in the three $F_{2}$ populations. One set was inoculated with whiteflies viruliferous for TYLCV, and the other set with whiteflies viruliferous for ToMoV, using the method described by Griffiths and Scott (2001). In this method, plants $20 \mathrm{~d}$ past the cotyledon stage are challenged with viruliferous whiteflies for $14 \mathrm{~d}$. After inoculation, the whiteflies were killed and plants were planted in separate field plots for each disease. The plants were set on $84-\mathrm{cm}$-wide $\times 20$-cm-high beds of EauGallie fine sand. The beds were spaced on $150-\mathrm{cm}$ centers with seepage irrigation ditches spaced six beds apart. The blocks were arranged parallel to the beds and the irrigation ditches. The plants were spaced at $46 \mathrm{~cm}$, with $91 \mathrm{~cm}$ between plots within the bed. Standard growing practices were followed (Hochmuth et al., 1999). Plots were grown randomly with 10 plants per plot for the parents, and 45 per plot for the $\mathrm{F}_{2}$ plants. Plants were rated for disease severity $45 \mathrm{~d}$ after the inoculation began. The rating scale was from 0.0 to 4.0 , where $0=$ no symptoms and 4 $=$ severe symptoms and stunting.

DNA was extracted from the young leaves of $90 \mathrm{~F}_{2}$ plants of each population as described by Griffiths and Scott (2001). The strategy for identifying RAPD markers linked to resistance genes was described previously (Agrama and Moussa, 1996; Michelmore et al., 1991). The polymorphic markers revealed by the previous work of Griffths (1998) and Griffiths and Scott (2001) were used in this study to construct genetic linkage maps for the three populations and to integrate these maps.

Data were compiled from each population, and two-point linkages between all RAPD markers and the phenotypic $s p$ marker were estimated. JoinMap 3.0 (van Ooijen and Voorrips, 2001) was used to construct maps of chromosome 6 for each of the populations and to construct an integrated map. To construct an integrated map of the three individual maps, the pairwise recombination frequencies for each cross were combined and one linkage group for the merged set was formed at logarithmic odds $(\mathrm{LOD}) \geq 3$.0. Threshold for declaring linkage was a LOD score of 4.0. Map units (cM) were derived using the Kosambi mapping function (Kosambi, 1944).

A computer software package, MapQTL version 3.0 (van Ooijen and Maliepaard, 1996), was used for interval mapping (Lander and Botstein, 1989). In the region of the putative QTLs (LOD>2.5), the markers with the highest LOD values were taken as co-factors for running a MQM program method (Jansen, 1993; Jansen and Stam, 1994). A LOD value of 2.5 was chosen as the significant threshold value for declaring a QTL.AQTL was retained when statistics exceeded the threshold defined above for both the Kruskal-Wallis test and the MQM. We arbitrarily considered that two QTLs had the same map position when LOD-score peaks were less distant than $20 \mathrm{cM}$ (Lespinasse et al., 2000). QTLs were named by a five-letter abbreviation for the virus name followed by the number of QTL found.

\section{Results}

The three resistant parents were highly resistant to both TYLCV and ToMoV, as expected (Table 1). Since disease severity for some of the susceptible parents was less than 3 , there were

Table 1. Parental lines and L. chilense $\mathrm{F}_{2}$ LA1932 (genotype 503), LA2779 (genotype 506), and LA1938/Tyk (genotype 509) populations information and their responses to tomato yellow leaf curl virus (TYLCV) and tomato mottle virus (ToMoV). Plants were rated for disease severity at $45 \mathrm{~d}$ after the inoculation.

\begin{tabular}{llll}
\hline & \multicolumn{1}{c}{$\begin{array}{c}\text { Resistance } \\
\text { source }\end{array}$} & \multicolumn{2}{c}{ Disease severity $(\mathrm{mean} \pm \mathrm{SE})^{\mathrm{z}}$} \\
\cline { 3 - 4 } Genotype & ToMoV & TYLCV \\
\hline 503P1 & & $0.0 \pm 0.00^{\mathrm{z}}$ & $0.0 \pm 0.00$ \\
$503 \mathrm{P} 2$ & & $3.5 \pm 0.27$ & $1.8 \pm 0.65$ \\
$506 \mathrm{P} 1$ & LA2779 & $0.0 \pm 0.0$ & $1.3 \pm 0.39$ \\
$506 \mathrm{P} 2$ & & $2.5 \pm 0.23$ & $2.6 \pm 0.48$ \\
$509 \mathrm{P} 1$ & LA1938/Tyking & $1.0 \pm 0.05$ & $0.9 \pm 0.10$ \\
$509 \mathrm{P} 2$ & & $3.5 \pm 0.00$ & $3.3 \pm 0.34$ \\
$503 \mathrm{~F}_{2}$ & LA1932 & $1.4 \pm 0.22$ & $0.8 \pm 0.15$ \\
$506 \mathrm{~F}_{2}$ & LA2779 & $1.6 \pm 0.24$ & $0.9 \pm 0.13$ \\
$509 \mathrm{~F}_{2}$ & LA1938/Tyking & $2.3 \pm 0.17$ & $1.5 \pm 0.18$ \\
\hline
\end{tabular}

$\overline{\text { Rating scale was from } 0 \text { to } 4 \text {, where } 0=\text { no symptoms and } 4=\text { severe }}$ symptoms and stunting. 
some plants that escaped infection; it can be assumed that the $\mathrm{F}_{2}$ plants also had some susceptible escapes. The $506 \mathrm{~F}_{2}$ population segregated in a $3: 1$ ratio for indeterminate $\left(s p^{+}\right)$: determinate $(s p)$ plant habit with $\chi^{2}$ value of $0.010(P=0.76)$. Frequency distributions of TYLCV and ToMoV severity ratings $80 \mathrm{~d}$ after inoculation for the three $\mathrm{F}_{2}$ populations and their parents are presented in Fig. 1. Disease severity to TYLCV and ToMoV in the three $\mathrm{F}_{2}$ populations approximated normal distributions (Fig. 1).

BSA identified 83 repeatable polymorphisms among the three sources. Present study of these 83 loci yielded a total of 55 polymorphic markers among the three populations. JoinMap was used to generate three individual maps of chromosome 6 . Of the 55 polymorphic markers, 28, 25, and 27 markers associated with TYLCV and/or ToMoV resistance on chromosome 6 in population 503, 506 and 509, respectively (Fig. 2). Population 506 was evaluated with the 25 linked RAPD markers together with the $s p$ locus that is assigned to chromosome 6 . When the
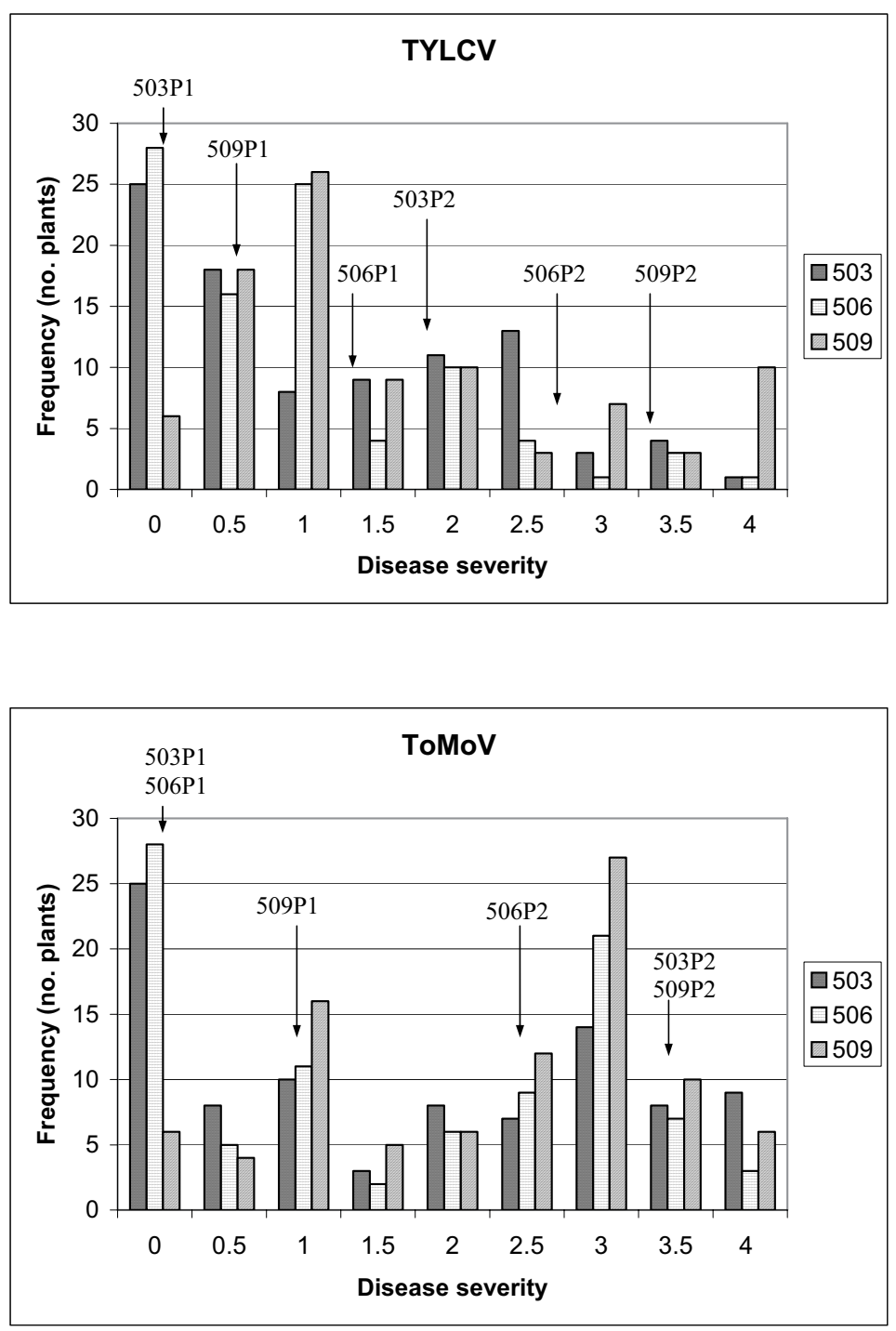

Fig 1. Frequency distribution of phenotype rates for the tomato yellow leaf curl virus (TYLCV) and tomato mottle virus (ToMoV) virus resistance in the three $\mathrm{F}_{2}$ populations derived from L. chilense genotypes LA1932 (genotype 503), LA2779 (genotype 506) and LA1938/Tyk (genotype 509). Values of the resistant (P2) and susceptible (P1) parental lines are shown by arrows. Plants were rated for disease severity on $45 \mathrm{~d}$ after the inoculation. The rating scale was from 0 to 4 , where $0=$ no symptoms and $4=$ severe symptoms and stunting. three maps were compared with each other, the 506 linkage map was shorter than the other two.

RAPD bands that migrated to identical positions on the gel and segregated in both pairs of parents were considered to be homologous markers. Six mapped markers were homologous in all three populations. Twelve, nine, and 14 RAPDs were homologous in two of three populations: either 506 and 509, 503 and 506 , or 503 and 509, respectively. The positions of homologous markers in the three $\mathrm{F}_{2}$ population linkage maps showed close conservation of marker order even though the populations were derived from different backgrounds. The marker order between maps was highly similar, with some minor rearrangements of markers at small intervals of less than $4.0 \mathrm{cM}$.

The traits were coded in the mapping analysis according to the observed disease severity. As a wide and continuous range of resistance scores in $\mathrm{F}_{2}$ plants was observed, the conclusion was drawn that the resistance was a multigenic trait. Scores for the disease screening were analyzed with Kruskal-Wallis rank test performance, which analyses only evaluated effects at the marker loci using a single QTL model. In the three genotypes, 503 (LA1932), 506 (LA2779), and 509 (LA1938/Tyking) differed in disease score. Significance ranged from $P<0.05$ for TYLCV in LA2779 to $P<0.0001$ for TYLCV2 in the 503 and 509 populations (Table 2). The unlinked markers did not show any association with the resistance in the three populations. To dissect and map the underlying genes, we performed QTL mapping on each data set for each disease separately. We applied MQM methods to map QTLs for resistance on chromosome 6 in the three populations. These revealed that the resistance against TYLCV and ToMoV was mainly explained by two QTLs in the 503 and 509 populations and one QTL in 506 (Table 2, Fig. 2).

QTLs for TYLCV and ToMoV in the population 503 (LA1932) were mapped in two different regions $\approx 45$ cM apart. One major QTL (TYLCV 2), peak at marker 389-855, was detected at a LOD score higher than 7.0. It contributed to at least $46 \%$ of the phenotypic variance. The other QTL, TYLCV1, was considered major with a LOD score of 3.9, and contributed $34 \%$ of phenotypic variance. Two major QTLs were detected for ToMoV (1 and 2) in the same positions as TYLCV with an approximate LOD score of 6.0, and contributed $30.7 \%$ and $39.3 \%$ of the phenotypic variance, respectively (Table 2). Only one QTL was detected for resistance to both diseases in population 506 (LA2779) on the far end of chromosome 6, with LOD scores of 3.4 and 4.1 for ToMoV and TYLCV, respectively (Table 2, Fig. 2). The contributions of this QTL were $29.8 \%$ and $47.5 \%$ of the TYLCV and ToMoV phenotypes, respectively. Two major QTLs were detected for disease resistance in population 509 (LA1938/Tyking). QTLs for TYLCV1 and ToMoV1 were mapped $15 \mathrm{cM}$ apart in the center region of the chromosome, with LOD scores of 5.7 and 5.3, respectively. The second QTL contribution to the phenotypic variance was $35 \%$ and $29.7 \%$ for TYLCV2 and ToMoV2 with LOD scores of 4.7 and 3.8 , respectively.

In summary, three different regions were found to be associated with resistance to TYLCV and ToMoV on chromosome 6 (Fig. 2). Flanking RAPD markers $697-$ 1225 and 053-760 in background genotype LA2779 are good candidates for resistance screening to both viruses. 
$503 / 1932$

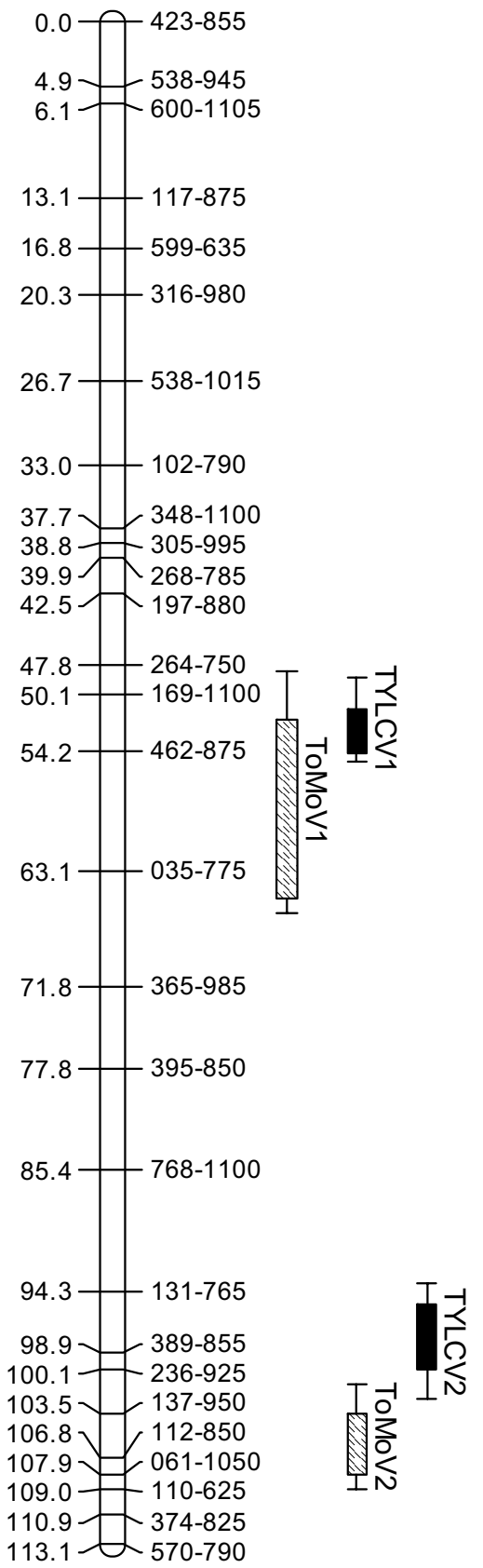

$506 / 2779$

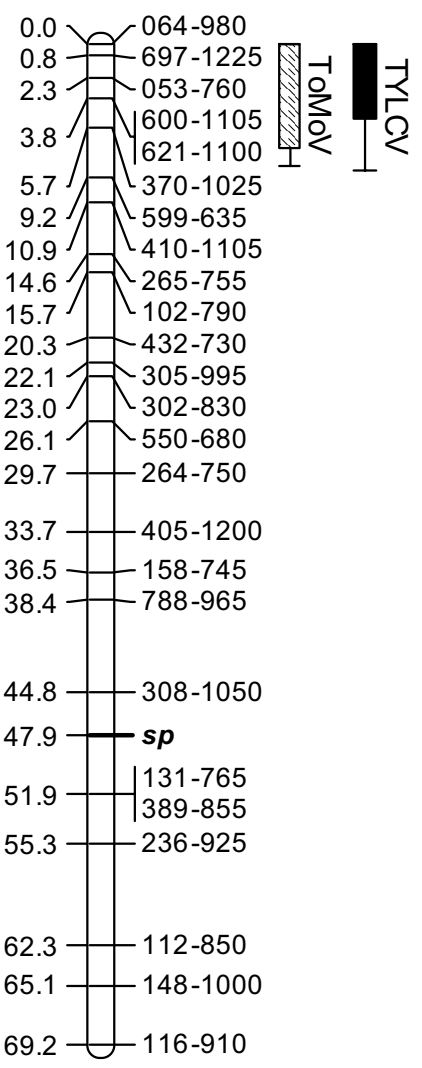

509/1938,Tyking

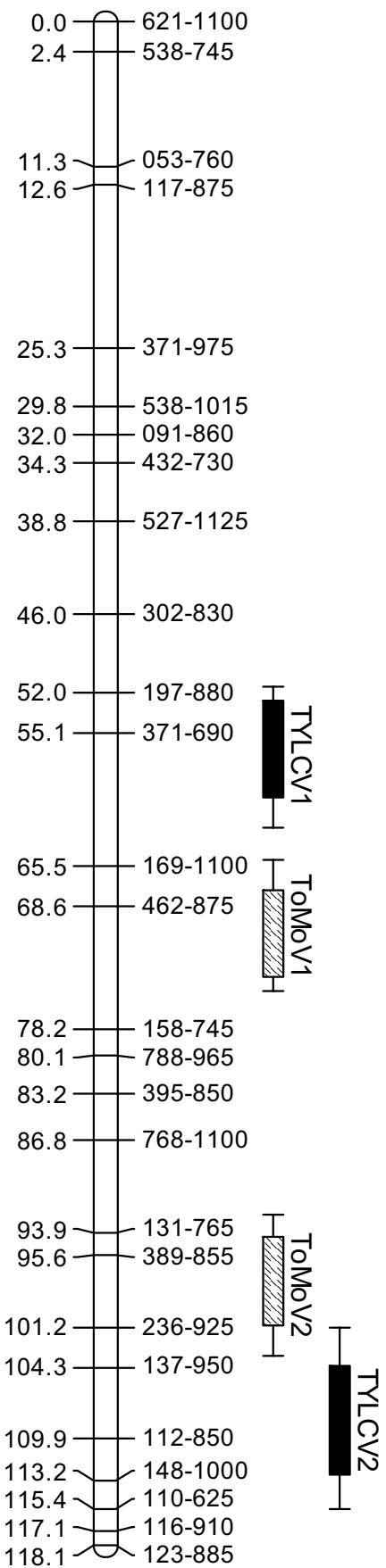

Fig 2. RAPD map of the chromosome 6 with the positions of QTLs for tomato yellow leaf curl virus (TYLCV) and tomato mottle virus (ToMoV) resistance in tomato. QTLs are shown beside the linkage maps developed from three L. chilense $\mathrm{F}_{2}$ populations. Bars indicate the QTL interval in which the inner bar shows a one logarithmic odds score (LOD) support confidence interval and the outer bar shows a two LOD support confidence interval. $s p$ allele is shown in bold italic in the 506 population. Map distances at the left of each map are in Kosambi functions, expressed as centiMorgans.

Likewise 389-855 and 169-1100 are good candidates for TYLCV resistance derived from LA1932, while 371-690 and 112-850 are good candidates in LA1938/Tyking genetic backgrounds. Two peak markers (035-775, 061-1050) were found to be associated with ToMoV resistance in the LA1932 population. However, markers 462-875 and 389-855 are good candidates in screening for resistance to ToMoV in LA1938/Tyking backgrounds. As expected, for all QTLs the favorable allele (i.e., the allele providing resistance) was inherited from the resistant parents.

\section{Discussion}

Bulk segregant analysis was applied previously to map RAPD markers linked to ToMoV resistance (Griffiths and Scott, 2001). The resistance was found to be associated with markers mapped to chromosome 6. Conventional genetic analysis and molecular genetic mapping in three $\mathrm{F}_{2}$ populations have found three regions for resistance to TYLCV and ToMoV. To our knowledge, this is the first report of different sources for resistance to geminiviruses in L. chilense. Saturation mapping of RAPD markers on 
Table 2. Detected QTL for tomato yellow leaf curl virus (TYLCV) and tomato mottle virus (ToMoV) resistance in the three $\mathrm{F}_{2}$ L. chilense populations with proportion of the explained phenotypic variance (Exp\%) and additive effect (Add) of the resistance allele. QTL were identified if the Kruskal-Wallis test or restricted multiple-QTL mapping (MQM) mapping was exceeded. QTL are presented per virus type from the disease test with the highest logarithmic odds (LOD) score.

\begin{tabular}{|c|c|c|c|c|c|c|}
\hline \multirow[b]{2}{*}{ Population } & \multirow[b]{2}{*}{ QTL name } & \multirow[b]{2}{*}{ QTL interval } & \multirow{2}{*}{$\begin{array}{l}\text { Kruskal-Wallis } \\
\text { significance test }\end{array}$} & \multicolumn{3}{|c|}{ Restricted MQM mapping } \\
\hline & & & & Peak LOD score & Exp\% & Add \\
\hline \multirow[t]{4}{*}{503} & TYLCV1 & $50.8-54.2$ & $* *$ & 3.9 & 34.1 & 1.2 \\
\hline & TYLCV2 & $95.1-99.8$ & $* * * *$ & 7.5 & 46.4 & 1.7 \\
\hline & ToMoV1 & $51.2-64.1$ & $* * *$ & 6.2 & 30.7 & 1.1 \\
\hline & ToMoV2 & $103.4-107.6$ & $* * *$ & 5.8 & 39.3 & 1.5 \\
\hline \multirow[t]{2}{*}{506} & TYLCV & $0.0-3.7$ & $*$ & 3.4 & 29.8 & 0.8 \\
\hline & ToMoV & $0.0-4.8$ & $* * *$ & 4.1 & 47.5 & 1.9 \\
\hline \multirow[t]{4}{*}{509} & TYLCV1 & $52.0-60.9$ & $* * *$ & 5.7 & 30.3 & 0.9 \\
\hline & TYLCV2 & $104.1-113.0$ & $* * * *$ & 8.1 & 35.0 & 1.2 \\
\hline & ToMoV1 & $67.5-74.1$ & $* * *$ & 5.3 & 24.6 & 1.0 \\
\hline & ToMoV2 & $94.0-101.2$ & $* *$ & 3.8 & 29.7 & 0.8 \\
\hline
\end{tabular}

chromosome 6 surrounding the resistance genes in L. chilense identified markers more tightly linked to resistance than those previously found in one population (Griffiths and Scott, 2001). Also, it enabled the construction of individual genetic maps for each of three populations derived from different sources. Common mapped markers revealed straightforward homologies between the chromosome 6 linkage group of the three populations.

The two-gene nature of the new source of resistance makes it particularly useful in breeding for virus resistance in light of the common accessions to tomato breeding. The major gene nature also means that a genetic MAS can easily be identified. MAS would thus become an available tool for breeding TYLCV and $\mathrm{ToMoV}$ resistance wherever the disease is found in the world. We applied interval mapping and MQM methods to map QTL for resistance on chromosome 6 in the three populations. A major improvement in the accuracy of QTL mapping was achieved by using MQM where the "peak" markers were taken as co-factors. Therefore, QTLs identified using MQM methods were considered to be the most reliable (Jansen, 1993; Jansen and Stam, 1994). The information from the current linkage groups will be used in a further QTL analysis study with emphasis on geminivirus resistance associated traits. An integrated genetic linkage map of chromosome 6 will be generated based on common markers. It can also be used as a starting point for a positional cloning strategy, as has been reported for Arabidopsis thaliana (L.) Heynh. (Cao et al., 1997; Leyser et al., 1993), tomato (Brommonschenkel and Tanksley, 1997; Martin et al., 1993), Oryza sativa L. (Song et al., 1995; Yoshimura et al., 1998), grapevines (Dalbó et al., 2000), and Zea mays L. (Agrama et al., 2002).

Assuming the estimated physical size of the tomato genome as $8.33 \times 10^{8} \mathrm{bp}$ (Peterson et al., 1998) and the genome size as $1300 \mathrm{cM}$ (Grandillo and Tanksley, 1996; Tanksley et al., 1992) leads to an estimate of $640 \mathrm{~kb} / \mathrm{cM}$. If this estimate applies to the genomic region surrounding the resistance genes (R genes), there would an opportunity to clone $\mathrm{R}$ genes by chromosome-landing strategy (Tanksley et al., 1995). Also, an alternative strategy is being pursued to clone $(\mathrm{R})$ genes, such as cloning resistance genehomologous by PCR (Michelmore, 1996; Staskawick et al., 1995). Nevertheless, high-resolution mapping of $R$ genes will facilitate this or other strategies, especially if resistance genes are clustered in linked arrays on chromosomes (Witsenboer et al., 1995).

The presence of three different sources of TYLCV and ToMoV resistance, and the markers in tight linkage with them, provide a means of systemically combining multiple resistance genes. Successful cloning of $\mathrm{R}$ genes from tomatoes would lead to deeper understanding of the molecular basis of resistance to TYLCV and $\mathrm{ToMoV}$, and might also shed light on the evolution of resistance genes in plants in general. The current research identified diagnostic tools that could be developed to screen tomato populations for presence of $\mathrm{R}$ genes without expensive and time-consuming progeny testing. Furthermore, R genes might be introduced into genomes of other susceptible lines where no, or only weak, TYLCV and ToMoV genetic resistance has been identified.

\section{Literature Cited}

Abouzid, A.M., J.E. Polston, and E. Hiebert. 1992. The nucleotide sequence of tomato mottle virus; A new geminivirus isolated from tomatoes in Florida. J. Gen. Virol. 73:3225-3229.

Agrama, H.A., S.F. Houssin, and M.A. Tarek. 2002. Cloning of AFLP markers involved in resistance to Peronosclerospora sorghi in maize. Mol. Genet. Genomics 276:814-819.

Agrama, H.A. and M.E. Moussa. 1996. Identification of RAPD markers tightly linked to the dwarf mosaic virus resistance gene in maize. Maydica 41:205-210.

Avgelis, A.D., N. Roditakis, C.I. Dovas, N.I. Katis, C. Varveri, N. Vassilakos, and F. Bem. 2001. First report of tomato yellow leaf curl virus on tomato crops in Greece. Plant. Dis. 85:678.

Brommonschenkel, S.H. and S.D. Tanksley. 1997. Map-based cloning of tomato genomic region that spans the $\mathrm{Sw}-5$ tospovirus resistance gene in tomato. Mol. Gen. Genomics 256:121-126.

Cao, H., J. Glazebrook, J.D. Clarke, S. Volko, and X. Dong. 1997. The Arabidopsis NPR1 gene that controls systemic acquired resistance encodes a novel protein containing ankyrin repeats. Cell 88:57-63.

Chagué, V., J.C. Mercier, M. Guénard, A. de Courcel, and F. Vedel. 1997. Identification of RAPD markers linked to a locus involved in quantitative resistance to TYLCV in tomato by bulked segregant analysis. Theor. Appl. Genet. 85:671-677.

Cohen, S., J. Kern, I. Harpaz, and M. Bar-Joseph. 1988. Epidemiological studies of the tomato yellow leaf curl virus (TYLCV) in Jordan Valley, Israel. Phytoparasitica 16:259-270.

Dalbó, M.A., G.N. Ye, N.F. Weeden, H. Steikellner, K.M. Sefc, and B.I. Reisch. 2000. A gene controlling sex in grapevines placed on a molecular marker-based genetic map. Genome 43:333-340.

Dry, I.B., J.E. Rigden, L.R. Krake, P.M. Mullineaux, and M.A. Rezaian. 1993. Nucleotide sequence and genome organization of tomato leaf curl geminivirus. J. Gen. Virol. 74:147-151.

Gomez, O. and H. Laterrot. 1997. Herencia de la resistencia al virus 
del encrespamiento amarillo de las hojas del tomate (TYLCV) en Lycopersicon chilense. Agrotecnia-de-Cuba 27:38-42.

Grandillo, S. and S.D. Tanksley 1996. Genetic analysis of RFLPs, GATA microsatellites and RAPDs in a cross between L. esculentum and $L$. pimpinellifolium. Theor. Appl. Genet. 92:957-965.

Griffiths, P.D. 1998. Inheritance and linkage of geminivirus resistance genes derived from Lycopersicon chilense Dunal in tomato (Lycopersicon esculentum Mill.). PhD Diss., Univ. of Florida, Gainesville.

Griffiths, P.D. and J.W. Scott. 2001. Inheritance and linkage of tomato mottle virus resistance genes derived from Lycopersicon chilense accession LA1932. J. Amer. Soc. Hort. Sci. 126:462-467.

Hanson, P.M., D. Bernacchi, S.D. Tanksley, V. Muniyappa, A.S. Padmaja, H. Chen, G. Kuo, D. Fang, and J. Chen. 2000. Mapping a wild tomato introgression associated with tomato leaf curl virus resistance in a cultivated tomato line. J. Amer. Soc. Hort. Sci. 125:15-20.

Hassan, A., H. Mazyad, S. Moustafa, S. Nassar, M. Nakhla, and W. Sims. 1984. Inheritance of resistance to tomato yellow leaf curl virus derived from Lycopersicon cheesmanii and Lycopersicon hirsutum. HortScience 19:574-575.

Hassan, A.A. and K.E.A. Abdel-Ati. 1999. Genetics of tomato yellow leaf curl virus tolerance derived from Lycopersicon pimpinellifolium and Lycopersicon pennellii. Egyptian J. Hort. 26:323-338.

Hochmuth, G.J., D.N. Maynard, C.S. Vavrina, W.M. Stall, T.A. Kucharek, and P.A. Stansly. 1999. Tomato production in Florida, p. 238-241. In: D.N. Maynard and G.J. Hochmuth (eds.). Vegetable production guide for Florida. Publ. SP 170, Univ. of Florida, Gainesville.

Ioannou, N. 1987. Cultural management of tomato yellow leaf curl disease in Cyprus. Plant Pathol. 36:367-373.

Jansen, R.C. 1993. Interval mapping of multiple quantitative trait loci. Genetics 135:205-211.

Jansen, R.C. and P. Stam. 1994. High resolution of quantitative traits into multiple loci via interval mapping. Genetics 136:1447-1455.

Kasarawi, M.A. 1989. Inheritance of resistance to tomato yellow leaf curl virus in Lycopersicon pimpinellifolium. Plant Dis. 73:435-437.

Kosambi, D.D. 1944. The estimation of map distances from recombination values. Ann. Eugen. 12:172-175.

Kring, J.B., D.J. Schuster, J.F. Price and G.W. Simone. 1991. Sweet potato whitefly-vectored geminivirus on tomato in Florida. Plant Dis. 75:1186.

Lana, A.F. and G.F. Wilson. 1976. A new viruslike disease of tomato in Nigeria. Plant Dis. Rptr. 60:296-298.

Lander,E.S. and D. Botstein. 1989. Mapping Mendelian factors underlying quantitative traits using RFLP linkage maps. Genetics 121:185-199.

Lespinasse, D., L. Grivet, V. Troispoux, M. Rodier-Goud, F. Pinard, and M. Seguin. 2000. Identification of QTLs involved in the resistance to South American leaf blight (Microcyclus ulei) in the rubber tree. Theor. Appl. Genet. 100:975-984.

Leyser, H.M.O., C.A. Lincoln, C. Timpte, D. Lammer, J. Turner, and M. Estelle 1993. Arabidopsis suxin-resistance gene Axr1 encodes a protein related to ubiquitin-activating enzyme E1. Nature 364:161-164.

Martin, G.B., S.H. Brommonschenkel, J. Chunwongse, A. Frary, M.W. Ganal, R. Sprivey, T. Wu, E.D. Earle, and S.D. Tanksley. 1993. Mapbased cloning of a protein kinase gene conferring disease resistance in tomato. Science 262:1432-1436.

Michelmore R. 1996. Flood warning-Resistance genes unleashed. Nature Genet. 14:376-378.

Michelmore, R.W., I. Paran, and R.V. Kesseli. 1991. Identification of markers linked to disease-resistance genes by bulked segregant analysis: A rapid method to detect markers in specific genomic regions by using segregating populations. Proc. Natl. Acad. Sci. USA 88:9828-9832.

Momol, M.T., G.W. Simone, W. Dankers, R.K. Sprenkel, S.M. Olson, E.A. Momol, J.E. Polston, and E. Hiebert. 1999. First report of tomato yellow leaf curl virus in tomato in south Georgia. Plant Dis. 83:487.

Monci, F., J. Navas-Castillo, J.L. Cenis, A. Lacasa, A. Benazoun, and E. Moriones. 2000. Spread of tomato yellow leaf curl virus Sar from the Mediterranean Basin: Presence in the Canary Islands and Morocco. Plant Dis. 84:490.

Peterson, D.G., W.R. Pearson, and S.M. Stack. 1998. Characterization of the tomato (Lycopersicon esculentum) genome using in vitro and in situ DNA reassociation. Genome 41:346-356.

Picó, B., M.J. Díez, and F. Nuez. 1996. Viral diseases causing the greatest economic losses to the tomato crop. II. The tomato yellow leaf curl virus - A review. Scientia Hort. 67:151-196.

Pilowsky, M. and S. Cohen. 1974. Inheritance of resistance to tomato yellow leaf curl virus in tomatoes. Phytopathology 64:632-635.

Pilowsky, M. and S. Cohen. 1990. Tolerance to tomato yellow leaf curl virus derived from Lycopersicon peruvianum. Plant Dis. 74:248-250.

Polston, J.E., E. Hiebert, R.J. McGovern, P.A. Stanly, and D.J. Schuster. 1993. Host range of tomato mottle virus, a new geminivirus infecting tomato in Florida. Plant Dis. 77:1181-1184.

Polston, J.E., D. Bois, C.A. Serra, and S. Concepción. 1994. First report of a tomato yellow leaf curl-like geminivirus in the western hemisphere. Plant Dis. 78:831.

Polston, J.E., R.J. McGovern, and L.G. Brown. 1999. Introduction of tomato yellow leaf curl virus in Florida and implications for the spread of this and other geminiviruses of tomato. Plant Dis. 83:984-988.

Scott, J.W. and D.J. Schuster. 1991. Screening of accessions for resistance to the Florida tomato geminivirus. Tomato Genet. Coop. Rpt. 41:48-50.

Scott, J.W., M.R. Stevens, J.H. Barten, C.H. Thome, J.E. Polston, D.J. Schuster, and C.A. Serra. 1995. Introgression of resistance to whiteflytransmitted geminiviruses from Lycopersicon chilense to tomato, p. 357-367. In: D. Gerling and R.T. Mayer (eds.). Bemisia: Taxonomy, biology, damage, control and management. Intercept, Andover, U.K.

Song, W.Y., G.L. Wang, L.L. Chen, H.S. Kim, L.Y. Pi, T. Holsten, J. Gardner, B. Wang, W.X. Zhai, L.H. Zhu, C. Fauquet, and P. Ronald. 1995. A receptor kinase-like protein encoded by the rice disease resistance gene, Xa21. Science 270:1804-1806.

Staskawicz, B.J., F.M. Ausubel, B.J. Baker, J.G. Ellis, and J.D.G. Jones. 1995. Molecular genetics of plant disease resistance. Science 268:661-667.

Tanksley, S.D., M.W. Ganal, and G.B. Martin. 1995. Chromosome landing: A paradigm for map-based gene cloning in species with large genome. Trends Genet. 11:63-68.

Tanksley, S.D., M.W. Ganal, J.P. Prince, M.C. de Vincente, M.W. Bonierbale, P. Broun, T.M. Fulton, J.J. Giovannoni, S. Grandillo, G.B. Martin, R. Messeguer, J.C. Miller, L. Miller, A.H. Paterson, O. Pineda, M.S. Roder, R.A. Wing, W. Wu, and N.D. Young. 1992. High-density molecular linkage maps of the tomato and potato genomes. Genetics 132:1141-1160.

van Ooijen, J.W. and C. Maliepaard. 1996. MapQTL version 3.0 software for calculation of QTL positions on genetic maps. Plant Res. Intl., Wageningen, The Netherlands.

van Ooijen, J.W. and R.E. Voorrips. 2001. JoinMap Version 3.0 Software for the calculation of genetic linkage maps. Plant Res. Intl., Wageningen, The Netherlands.

Verma, H.N., K.M. Srivastava, and A.K. Mathur. 1975. A whiteflytransmitted yellow mosaic virus disease of tomato from India. Plant Dis. Rptr. 59:494-498.

Vidavsky, F., S. Leviatov, J. Milo, H.D. Rabinowitch, N. Kedar, and H. Czosnek. 1998. Response of tolerant breeding lines of tomato, Lycopersicon esculentum, originating from three different sources $(L$. peruvianum, L. pimpinellifolium and $L$. chilense) to early controlled inoculation by tomato yellow leaf curl virus (TYLCV). Plant Breeding 117:165-169.

Witsenboer, H., R.V. Kesseli, M.G. Fortin, M. Stanghellini, and R.W. Michelmore. 1995. Sources and genetic structure of a cluster of genes for resistance to three pathogens in lettuce. Theor. Appl. Genet. 91:178-188.

Yoshimura, S., U. Yamananouchi, Y. Katayose, S. Toki, Z.X. Wang, I. Kono, N. Kurata, M. Yano, N. Iwata, and T. Sasaki. 1998. Expression of $X a 1$, a bacterial blight-resistance gene in rice, is induced by bacterial inoculation. Proc. Nat. Acad. Sci. USA 95:1663-1668.

Zamir, D., I. Ekstein-Michelson, Y.Zakay, N. Navot, M.Zeidan, M. Safatti, Y. Eshed, E. Harel, T. Pleban, H. van-Oss, N. Kedar, H.D. Rabinowitch, and H. Czonek. 1994. Mapping and introgression of tomato yellow leaf curl virus tolerance gene, Ty-1. Theor. Appl. Genet. 88:141-146. 